\title{
Tunisian Financial System: A Growth Factor
}

\author{
Imène Ben Fredj \\ ISG Tunis \\ Résidence Jannet 2, D18 office, 2045 Aouina Tunis, Tunisie \\ Tel: 21-6-9837-3237 E-mail: imenebf@yahoo.fr \\ Christophe Schalck \\ ESG Management School \\ 25 rue Saint Ambroise, 75011 Paris, France \\ Tel: 33-1-5336-4434 E-mail: cschalck@pole-esg.fr
}

\begin{abstract}
The relationship between financial development and economic growth were the subject of many recent theoretical and empirical works. These works generally focused on link between finance and growth according to the maturity of financial systems. The Tunisian economy knew a long period of financial repression before starting several phases of liberalization. The aim of the paper is to determinate the impact of the development of the Tunisian financial system on economic growth. We identified economic and financial development indicators of Tunisian economy. The empirical study on Tunisia is based on causality tests within B-VAR framework. Reciprocal relationships are only finding between the ratio of investment on GDP and the loans granted to private and public sectors. The economic role of government is highlighted, over the pre-reforms period as well as during the recent time.
\end{abstract}

Keywords: Financial repression, Finance and Growth, B-VAR

\section{Introduction}

The relationship between financial development and economic growth was the subject of many recent theoretical and empirical works (Gylfason, 2004; Rioja and Valev, 2003; Driffill, 2003; Haas, 2002; Carlin and Mayer, 2000). These authors generally focused their analysis on the link between finance and economic growth according to the maturity of financial systems. As the Tunisian economy knew a long period of financial repression before liberalization, it would be judicious to start by McKinnon and Shaw's theory of "financial deepening" (1973) to then determinate the impact of the development of the Tunisian financial system on economic growth. McKinnon and Shaw were the first authors which analyze negative effects of financial repression's policy on economic performance. Their theory links economic growth to saving development and thus to financial system development. They defined financial liberalization as an effective and simple tool to accelerate economic growth rate of less developed countries (LDC). This theory quickly found an important echo near international organizations and some LDC that started to install financial liberalization mechanisms: give up administration rates, suppression of excessive interventions of Official Authorities, open the economy to foreign trade...

The process of financial liberalization has been applied in many LDC countries, in particular in Latin America and in the Southeast Asia. What are the effects of these changes on the operation of financial systems? Did the countries which adopted a liberal policy, really reach a stage of economic growth more sustained? In the countries of the Latin America such as Chile, financial liberalization was total and induced with a failure resounding. The Chilean economy knew successive bankrupts of as well banks as firms. The government was obliged to reestablish a minimum authorized capital but the credit institutions in difficulty did not receive any help of the monetary authorities and consequently no guarantee of the deposits of the agents could be assured. As for the countries of Southeast Asia like South Korea and Taiwan, this process introduced gradually and involved a light improvement of the saving. By this way, these two countries reached a stage of exceptional economic development.

Tunisia has applied since 1986 the mechanisms of financial liberalization by giving up the fixing of the interest rates by the Official Authorities, namely the Central Bank of Tunisia. How Tunisia did start its liberal policy? What were the impacts of such a policy on the country development?

To study the relationship between finance and growth, King and Levine (1993) based their analysis on the growth model of Solow. This approach is implicitly present in the empirical study of Boulila and Trabelsi (2002) on Tunisia; this study shows that a bilateral relation between finance and growth exists only between the credit and private 
investment during the 1962-1997 period. However, the endogenous theories of growth appeared in the 1980's highlight the role of the government in the accumulation of the capital. As the economic development of Tunisia were driven by a significant public sector and the financiarisation occurred under the impulse of the government, it would be interesting to see whether there are causality relationships between the financial development, the private capital, and the public capital and if these links were modified with the reforms of 1986. Consequently, we improve the study of King and Levine (1993) by incorporating an endogenous model of growth. The analysis of the relationship between finance and growth in Tunisia is carrying out through a double analysis: a correlations analysis and a B-VAR estimation.

The paper is organized as follows: section 2 clarifies the bases of the theory of "the financial deepening" developed by McKinnon and Shaw (1973), checks its validity on the Tunisian case. Section 3 develops problems arising from financial liberalization, section 4 presents the indicators of growth and the financial development and analyzes causalities between these variables through a B-VAR, and section 5 concludes.

\section{A harmful financial repression to the growth}

The model of "financial deepening" of McKinnon and Shaw regards the monetary expansion as being the result of the increase in saving, which justifies their principal normative conclusion namely the abandoning of reaching a ceiling of interest rates.

\subsection{The supremacy of currency in $L D C$.}

McKinnon and Shaw (1973) focused on the M2 monetary aggregate. They consider "Money as in a theory of finance", in which the money demand is a positive function of saving. They explained that the segmentation of LDC blocks the rise of capital markets. In this environment, the currency constitutes the only financial asset being used like holds value. Therefore, the currency is the central element of the process saves and consequently the condition necessary to the economic growth. The importance of the currency as a reserve of value compared to other financial assets remains a constant in LDC. From this observation, McKinnon and Shaw developed their research of the optimal management of the currency which aims at showing the inefficiency of traditional managements and leads to a financial repression.

Table 1 shows the dominating place of M2 in Tunisia. The evolution of M2 is strong between 1980 and 1985 (M2 multiplied by more than twice) rather than during the period 1990 and 1995 (less supported variation) which proves that the role of the aggregate M2 was more significant before the 1986 reforms. The progress of an economy implied a permanent movement of the currency that drives business cycles. Rioja and Valev (2004a, 2004b) showed that the increasing relationship between financial development and economic growth is not uniform but varies according to the evolution of the countries, which depends mainly on economic agents' behavior.

\subsection{The management of interest rates and obligatory banking reserves}

\subsubsection{Misdeeds of reaching a ceiling of interest rates}

McKinnon and Shaw noted that is the high levels of inflation which characterize many LDC and push economic agents to prefer goods. The currency is only considered as a value reserve. Based on this observation, the two authors deduced that high interest rates are the main condition for financial development and thus for economic growth. A financial repression policy with a strong inflation would lead to a deceleration of the economic growth (Figure 1). Such a policy would imply negative real rates ((1) and (2)) and thus a reduction in deposits (5). This situation would compromise the creditor activity of banks (6) while encouraging the surplus credit demand (4). The credit rationing would engage, in its turn, a series of indirect negative effects. On the one hand, the practice of usury would take seat and the political nepotism would continue more as a decisive criterion in the credit granting. In addition, the economic concentration would be favored since the credits would go preferably to large companies which would be the only ones being able to offer under rarefaction conditions of sufficient guarantees credit; such a climate would discourage the innovation. The reaching a ceiling of interest rates leads ultimately to a bad allocation of resources, therefore to a deceleration of growth (11), additional source of contraction of financial system (12). According to McKinnon and Shaw, the reaching a ceiling of interest rates can also cause inflation. Indeed, it would lead to negative real interest rates and, so to a reduction in the saving and thus in the growth of money demand. However, according to the quantitative theory used, if this growth were to be lower than that of money offer (5), the economy would be subject to a rising of prices (7). The analysis leads the two authors to propose the liberalization of the interest rates like principal instrument of the "financial deepening". The monetary assets would become attractive stores of value able to engage the virtuous cycle.

The effects of the interest rate on the inflation and growth rates in Tunisia confirm the McKinnon and Shaw theory (Table 2): any increase in the real interest rate on the deposits is associated with a reduction of inflation and an 
increase of economic growth rate. It should be noted that year 2002 is characterized by a fall of growth rate $1.66 \%$ against 4.76\% into 2001 following the events of September 11 and April 11 (the catastrophe of Djerba). This is the reason why Gylfason (2004) emphasize the role of the price stability for a strong long-term growth.

Several works confirm that a financial system associated with an adequate lawful framework contributes considerably to stimulate economic growth (Haas, 2002). A large empirical work such as those of Demirgüc-Kunt and Maksimovic (2000), Beck, and Levine (2000) proved the importance of institutional aspect. Levine (1998) examined the positive impact of the legal environment on financial development and in particular, on the expansion of financial intermediaries, which allows to maintain a level constant of long-term growth. Avila (2003) shows the existence of a positive impact in the long term of the capital control liberalization and the banking legislation deregulation in United States.

\subsubsection{Consequences of the mode of obligatory reserves}

The normal use of the obligatory reserves as an instrument of monetary policy consists in controlling the supply of currency and thus inflation. Some LDC converts these reserves of instrument of monetary control into instrument of financial repression. The central Banks of these countries impose high rates of obligatory reserves in order to financing the public deficits and specialized agencies activity (3). This mechanism leads to credit banking rationing and to inflation (McKinnon and Shaw, 1973). Thus, coordinated suppression of reaching a ceiling of interest rates of obligatory reserves is essential to be able to overcome financial repression and particularly to face the problem of inflation.

The rate of obligatory reserves was the subject of frequent modifications according to the cash flow statement of the banks and the deficit of Tunisian government. Until May 1973, the obligatory reserves were calculated on the total of the deposits of month end and its rate was fixed at 8\%. However, as from March 31, 1980, the deposits placed in the foreign accounts in devises belonging to non-residents were deducted from the plate of obligatory reserves. The rate applied to this new plate dropped to $3 \%$ in 1980. From June 16, 1989, banks applied a rate equal to $2 \%$ of the plate consisted sight deposits in accounts resident and term accounts. Since May 16, 2002, the rate applied to incur sight deposits is always $2 \%$; on the other hand, the banks use a rate of $1 \%$ on term deposits instead of $2 \%$. Credits offered by banks know an increase with each modification with the fall in the obligatory reserves rate since banks devote a less part of their deposits to the central Bank, if there is a credit demand. As shows it above the data of the table, the credit granted to the economy passed from $104 \%$ of the deposits in 1980 to $111 \%$ in 1989 to reach $124 \%$ into 2002 .

The influence of the government on the performance of economies is widely discussed in the literature. Mayer and Sussman (2001) start from a national analysis of the relationship between financial development, government decisions and economic growth to then reach an international analysis, which makes it possible to compare a multitude of financial systems. Although the regulations of the adopted policies are generally strong and restrictive, a total prudence in the respect of aims by the Official Authorities is always recommended.

\subsubsection{Evolution of financial system in a liberal economy}

The control of inflation by the reduction in the inflationary financing obliges to seek another source of financing of the public deficit. To ensure a noninflationary financing of public expenditure, McKinnon and Shaw propose the adoption of tax reforms. Tunisia implements the Structural Plans of Adjustment carried out under international financial institutions. The tax reforms engaged by the government, particularly the institution of the value added tax (VAT), allowed an adjustment of public finance, a re-establishment of the external accounts and a significant retreat of inflation. Moreover, thanks to additional tax related to operations of privatization, the public deficit was brought back from 2.3\% of GDP in 1999 to $1.6 \%$ of GDP into 2000. Inflation and deficit were contained during the first eight months of year 2003 within the limits of $2 \%$ and $1.5 \%$ respectively. The IMF also suggested several reforms: widening of the taxable amount, suppression of the grants on the foodstuffs, reduction in the wage bill of the public sector.

\section{Problems arising from financial liberalization}

\subsection{The increasing relation between interest rate and saving}

The theory of financial repression supposes an increasing relation between real interest rate and saving. The theory takes the substitution effect into account, which implies an increase in saving when its remuneration increases. This positive relation is well checked in Tunisia (Table 4): during the period of administration's rates, the saving collected by Tunisian deposit banks rises with the level of creditor interest rates. However, the income effect could become the relation between the two variables ambiguous: in Tunisia, the bank deposits increase more quickly than investments what means than the liberalization of the interest rates does not imply a linear improvement of the economic situation of the country. 


\subsection{The perfection financial market hypothesis}

The approach of MacKinnon and Shaw is founded on the implicit assumption that the money market is a perfect market. This assumption is widely discussed since Stiglitz and Weiss (1981). They showed that, even on competitive markets of the banking financing, it could exist a credit rationed which means that financial liberalization can be ineffective. This is due to the imperfections of the credit market. Moreover, informational imperfections can easily lead banks to processes of anti-selection. In other words, if information is imperfect, the credit institution for example the bank can raise its creditor rates, will thus sanction all its debtors and give up profitable projects. This behavior would imply that firms will prefer riskier projects and bank will attract bad borrowers who will be not very sensitive to their insolvency.

\subsection{The transitory rigidity of the banks and the government}

The rise of the interest rates induced by financial liberalization can pose a transitory problem for the banking sector and the government, this problem comes from the necessary time to adapt their behaviour to new interest rates. Structurally, banks offer loans of an average maturity higher than that of the collected deposits. If these loans are at fixed rates and deposits rates increase related to financial liberalization, it implies a provisional reduction of the banking margin due to the increase of the cost of their resources. So the banking structure can undergo significant losses related to its processing of maturity change and be thus in a situation of transitory brittleness. For the government, a rise in interest rates has an incidence because it increases the interest burden. Moreover, financial liberalization could lead to cuts tax. Consequently, it could exist an optimal degree of financial repression because the absence of direct financial markets doing the government to bailout his public deficit (Bencivenga et Smith, 1991 and 2000, Roubini and Sala-i-Martin, 1991).

\subsection{The absence of an informal financial system}

The approach of McKinnon and Shaw does not take the presence of an informal financial sector into account that is one of the key features of LDC. On the one hand, official sector and informal sector would be substitutable and the growth of the first would lead inevitably to the disappearance of the second. On the other hand, the existence of an informal financial sector allows an adjustment between credit supply and demand (Taylor 1983). Loans on this market are thus substitutable with bank deposits. The rise of the rates pulled by the suppression of the restrictive rules stimulates the growth and has as consequence an increase in the credit costs on this market. Far being a handicap for the economic development, the abstract sector can consequently urge on the growth of the economy (Carlin and Mayer, 2000).

\section{Growth and financial development: empirical analysis}

\subsection{Indicators of growth and financial development}

\subsubsection{Indicators of economic growth}

The economic growth is analyzed through a standard model of endogenous growth, i.e. using the formalization of Barro and Sala-I-Martin (1992). The macroeconomic production function is a Cobb-Douglas function with constant returns. So $Y$ is the GDP in volume per capita, $K$ physical stock of capital per capita, and $G$ public expenditures per capita. The endogenous model of growth is written as follows:

$$
Y=A K^{\alpha} G^{(1-\alpha)}
$$

Taking logarithms and differencing yields:

$$
G Y=\alpha G K+(1-\alpha) G G
$$

where $G Y$ is the growth rate of real per capital GDP, $G K$ is the growth rate per capita physical capital stock and $G G$ is the growth rate per capita public expenditures.

Estimates of physical capital are Vikram and Dhareshwar ones (1993), but these estimates stop in 1990. Therefore, we add the estimate for the data of 1991 to 2003 starting from the traditional formulation of the accumulation of the capital.

$$
K_{t}=(1-\delta) K_{t-1}+I_{t}
$$

Where $I_{t}$ is the investment in the year $t$ and $\delta$ is the depreciation rate of capital. We use the apparent rate of depreciation since the years 1985 in Tunisia, which is 7\%. We also use the investment per capital as proxy of the growth of the stock of capital (INV). There are thus four indicating variables of growth $G Y, G K, I N V, G G$.

\subsubsection{Indicators of financial development}

We use variables of the financial development of King and Levine (1993) and we add the variables related to the 
financing of public expenditures by the Tunisian financial sector. There are thus six variables of the financial development. The first variable corresponds to the size of the financial intermediaries. The literature generally uses the share of the liquid assets on GDP (LLY) as representative variable of this size. The second variable reflects the importance of the trade banks in the financial system (BANK) by the intermediary of the banking capital ratios on total financial capital. The other variables represent the importance of the financing of the public and private sector carried out by the banking structure. We distinguish the share of the receivable amounts to the firms in the domestic credit (PRIVATE), the ratio of the amounts receivable to the firms in GDP (PRIVY); and in a reciprocal way, the share of the amounts receivable to the Government in the domestic credit (PUBLIC) and the ratio of the amounts receivable by the government in GDP (PUBLY). The two last variables are added in comparison to existing studies. These variables allow to understand the role of the Government in the economy since they reflects the financial impulse given by the public sector to the growth and the accumulation of the capital.

\subsection{Correlations analysis}

The data set corresponds to quarterly data over the 1963-2003 period. Since this study seeks to measure the impact of the reforms of financial liberalization on the Tunisian growth, we distinguish two sub-periods: 1963-1986 and 1987-2003.

We can note the existence of a link between the real sphere and the financial sphere through the study of the correlations. Our study shows that the auto-correlations of the same period between the variables financial and real (resulting from the production function) are weak even negative, which implies a little contemporary relationships between the two spheres (Table 5). Nevertheless, variable $I N V$ seems more sensitive to financial conditions since it is correlated to 0.87 with PRIVY and 0.84 with $L L Y$. The correlations between the financial and real variables are however more significant during the time 1987-2003. It is also noted that the financial variables are strongly correlated between them (up to 0.95). As the frequency of the study is quarterly, delays can exist in the adjustments of the variables. Therefore we examine lagged correlations. The study shows that the real variables (mainly growth of the GDP) are advanced indicators of the financial variables. Only the variable PUBLIC constitutes an advanced indicator of the growth and accumulation of capital. The role of the Government on the accumulation of the capital and the growth is significant which does not fit exactly with the views of McKinnon and Shaw model.

\subsection{B-VAR analysis}

First, we studied the stationarity and the presence of a deterministic tendency. We performed unit root tests and results show that the real variables are stationnary except for the investment. Conversely, the results of the tests indicate that the financial variables are non-stationary but they show the stationary in first difference. Thus, we use the first differences of the investment (DINV) and those of the financial variables (DBANK, DLLY, DPRIVATE, DPRIVY, DPUBLIC, DPUBLY). The no stationary character of the series invites to seek the presence of one or more stationary linear combinations between these variables. The existence of a relation of cointegration between the variables implies a study with a model with correction of errors and not starting from a VAR. We tested the existence of these relations using the usual test of Johansen and Juselius (1990) of the Likelhood ratio. The results show the non-cointegration from the series except for the variables PRIVATE and PUBLIC over the whole period, which are cointegred with the variables of accumulation of the capital. These relations of cointegration are not constant over the time: As a study in terms of VAR cannot be done using cointegred series, we chose to apply the methodology to the financial series, which are cointegred with no real series by a given sample. Consequently, the variables taken into account are (i) all real variables $(G Y, G K, G G, D I N V)$ and financial variables $D B A N K, D L L Y$, DPRIVY, DPUBLY for the 1963-2003 period; (ii) all real variables and financial variables DPRIVATE and DPUBLIC for the 1963-1986 period; (iii) all real variables and financial variables DPRIVATE, DPUBLIC, DPRIVY, and DPUBLY over the 1987-2003 period.

The methodology of B-VAR (Bivariate VAR) corresponds to the study of the interactions between two variables. More precisely it is a question here of seeing whether these variables are influenced mutually. For this purpose, we apply tests of causality to Granger with a bivariate model. A representation B-VAR with $p$ lags, can be formulated as follows:

$$
Y_{t}=\mu+\Sigma_{i=1}^{p} \phi_{i} Y_{t-i}+\varepsilon_{t}
$$

where $Y$ is made of two variables $Y_{l}$ and $Y_{2}, \mu$ is the vector of the constants, $\phi_{i}$ are the matrices of coefficients and $\varepsilon$ is the vector of the not correlated errors.

The test of Granger in a bivariate model indicates that the variable $Y_{2}$ is the cause of $Y_{l}$ if the predictability of $Y_{l}$ is improved when $Y_{2}$ is built-in in the analysis. Thus, the block of the lagged variables $Y_{2 t-i}$ is considered as exogenous compared to the block of the lagged variables $Y_{t t-i}$, if the fact of adding the $Y_{2 t}$ block significantly does not improve 
the determination of the variables $Y_{l t}$.

We applied tests of Granger in a structure B-VAR gathering a financial variable and a real variable. We thus tested on each variable representing the financial development with various variables of economic growth over the different periods. Results are synthesized in Table 6. They confirm those of Boulila and Trabelsi (2002) since they highlight a retroactive loop between the rate of investment (DINV) and the loans at the private sector (DPRIVY) over the 1963-2003 period. Moreover, our results show that loans to public sector (DPUBLY) play a role in the growth of the investment since they also show the existence of a retroactive loop. The analysis of sub-periods indicates that these directional bi-causalities are recent and seem related to financial liberalization. As opposed to what could let believe the study of the correlations, the influence of public expenditures or loans granted to the Government is not significant before 1986. Nevertheless, the impact of fiscal decisions on the financial development increased since the reforms: results show a causality of the growth of the public expenditure $(G G)$ towards the change in loans granted to the private sector. Moreover, we note the interaction between the loans granted by the financial system to the Government and the ratio of investment on GDP.

\section{Conclusion}

In a repressed financial system, interest rates are generally directly fixed by the monetary authorities at low levels. The most significant consequence of these forms of financial repression is the weakness of interest rates. Economic agents do not know any more where to invest the currency because they do not manage to obtain guide prices of the needs for the economy. It is difficult to establish a cost of the capital of a given economy since there is no reference to equilibrium. The strong specialization of the activities of the financial intermediaries and in fact of banks (deposit banks, development banks, insurance companies...) also results from financial repression. McKinnon and Schaw (1973) showed the harmful effect of the financial repression on economic growth. The concept of financial liberalization appeared in the writings of McKinnon and Shaw presents the liberalization of the financial sector like an effective and simple tool to accelerate the economic growth in developing countries. Tunisia is one of countries, which adopted since 1986, the McKinnon and Shaw views, which makes it possible to leave the financial distress. Nevertheless, fearing harmful effect that can result from a total liberalization, the Tunisian economy led with much prudence its liberal policy while following a step by step.

In order to determine the links between the financial sector and the real sector, we developed the model of King and Levine (1993) through an endogenous growth model. It allows to take the role of the public sector in the Tunisian economy into account. The results of our estimates show that, after the introduction of the reforms initiated since 1986, the growth of the loans to the public sector and the public expenditure affects the growth of the investment positively and consequently stimulates the growth of the economic activity. We distinguished sub-periods in order to take Tunisian institutional factors and specificity of the policies adopted by the Tunisian government during these two periods into account.

Our study could be extended within the framework of a VECM so as to take causalities of short term and long term into account. It could also return in account the new elements of research, which try to explain the nature of the relations, which can exist between the indicators of the financial sphere and the indicators of the real sphere according to different optics' (the legal and lawful framework, the regional factors, the specificity of the financial systems, cost of intermediation,..). Indeed, although these studies generally released the existence of a strong positive relation between these two sizes, extension of the financial system (associate with a coherent lawful system) as condition of the development remains in suspends.

\section{References}

Avila, D. (2003). Finance and Growth in the EU: New Evidence from the Liberalization and Harmonization of the Banking Industry, ECB Working Paper, 266.

Barro, R. Sala-i-Martin, X. (1992). Public Finance in Models of Economic Growth, Review of Economic Studies, 59(4), 645-661.

Beck, T. Levine, R. (2000). New Firm Formation and Industry Growth. Does Having Market-of Bank-Based System Matter?, World Bank Papers, 2383.

Bencivenga, V. Smith, B. (2000). Secondary Capital Markets, Long-Run Growth, and the Term Structure of Asset Yields, International Economic Review, 41(3), pp. 769-800.

Bencivenga, V. Smith, B. (1991). Financial Intermediation and Endogenous Growth, Review of Economic Studies, 58(2), pp. 195-209.

Boulila, G. Trabelsi, M. (2002). Financial Development and Long-Run Growth: Granger Causality in a bivariate 
VAR Structure, Evidence from Tunisia: 1962-1997, FSEGT Working Paper, September.

Carlin. W. Mayer, C. (2000). Finance, Investment and Growth, Contemporary Corporate Governance Conference, June.

Demirgüc-Kunt, A. Maksimovic, V. (2000). Funding Growth in Bank-Based and Market-Based Financial Systems: Evidence from Firm-Level Data, World Bank Working Paper, No 2432.

Driffil, J. (2003). Growth and Finance, Manchester School, 71, pp. 363-380.

Gylfason, T. (2004). Monetary and Fiscal Management, Finance and Growth, Fiscal Policy, Macroeconomics and Growth, CESIFO Working Paper, 1118.

Haas, R. (2002). Finance, Law and Growth during transition: a survey, DNB Staff Report, 74.

King, R., Levine R. (1993). Finance and Growth: Schumpeter might be right", Quarterly Journal of Economics, 108(3), pp.717-738.

Johansen, S., Juselius, K. (1990). "Maximum Likehood Estimation and Inference of Cointegration with Application to the Demand for Money", Oxford Bulletin of Economics and Statistics, 52(2).

Levine, R. (1998). Law, Finance, and Economic Growth, Journal of Financial Intermediation, 8(1), pp.8-35.

Mayer. C, Sussman. O, (2001), "The assessment: Finance, Law and Economic Growth", Oxford Review of Economic Policy, 17(4), pp. 457-466.

McKinnon, R. (1973). Money and Capital in Economic Development. The Brookings Institution, Washington DC.

Rioja, F. Valev, N. (2004). Finance and the Sources of Growth at Various Stages of Economic Development, Economic Inquiry, 42(1), pp. 127-140.

Rioja, F. Valev, N. (2004) Does One Size Fit All? A Reexamination of the Finance and Growth Relationship. Journal of Development Economics, 74(2), pp. 429-447.

Roubini, N, Sala-i-Martin, X. (1991). Financial Repression and Economic Growth, Working Paper, 3876.

Shaw, E. (1973). Financial Deepening in Economic Development, Oxford University Press, New York

Stiglitz, J., Weiss, A. (1981). Credit Rationing in Markets with Imperfect Information, American Economic Review, 71(3), pp. 393-410.

Taylor, L. (1983). Structuralist Macroeconomics: Applicable Models for the Third Wore, New York, Basic Books

Vikram, N., Dhareshwar, A. (1993). A new Database on Physical Capital Stock: Sources, Methodology and Results, Rivista de Analisis Economico, 8(1)

Table 1. Monetary aggregate M2 in Tunisia (million dinars)

\begin{tabular}{|c|c|c|c|c|c|c|}
\hline & 1980 & 1985 & 1987 & 1990 & 1995 & 2002 \\
\hline M2 & 1.445 & 3.162 & 3.813 & 5.570 & 7.803 & 17.042 \\
\hline
\end{tabular}

Source: Financial statistics of IMF

Table 2. Administrative interest rate, inflation and growth (\%)

\begin{tabular}{|c|c|c|c|c|c|c|c|}
\hline & 1983 & 1987 & 1992 & 1995 & 1997 & 2001 & 2002 \\
\hline Real interest rate & -4.40 & 0.02 & Free & Free & Free & Free & Free \\
\hline Inflation rate & 8.90 & 8.00 & 6.30 & 7.80 & 4.60 & 1.90 & 2.80 \\
\hline Growth rate & 4.68 & 4.90 & 7.80 & 2.34 & 5.44 & 4.76 & 1.66 \\
\hline
\end{tabular}

Source: Financial statistics of IMF, National institute of Statistics 
Table 3. Obligatory reserves in Tunisia

\begin{tabular}{|l|c|c|c|}
\hline & 1983 & 1987 & 1992 \\
\hline Obligatory reserves rate & $3 \%$ & $2 \%$ & $1 \%$ \\
\hline Credit to the economy (in bn dinars) (1) & 1.156 & 4.668 & 17.122 \\
\hline Monetary Deposits and quasi Money (in bn dinars) (2) & 1.113 & 4.194 & 13.815 \\
\hline$(1) /(2)$ & $104 \%$ & $111 \%$ & $124 \%$ \\
\hline
\end{tabular}

Source: Financial statistics of IMF, authors' computations

Table 4. Interest rate and save in Tunisia (Bn dinars)

\begin{tabular}{|c|c|c|c|c|c|c|c|}
\hline & 1980 & 1981 & 1983 & 1985 & 1987 & 1997 & 2002 \\
\hline Deposit Rate & 2.50 & 4.00 & 4.50 & 5.35 & 7.22 & Free & Free \\
\hline Banks deposit & 494.729 & 609.442 & 775.979 & 1103.199 & 1686.981 & 5654.754 & 10118.78 \\
\hline
\end{tabular}

Source: Financial statistics of IMF, National institute of Statistics

Table 5. Correlation analysis

\begin{tabular}{|c|c|c|c|c|c|c|}
\hline \multicolumn{7}{|c|}{ Contemporaneous correlations } \\
\hline $1963-2003$ & BANK & LLY & PRIVATE & PRIVY & PUBLIC & PUBLY \\
\hline GG & -0.007 & -0.132 & -0.081 & -0.126 & -0.081 & -0.225 \\
\hline GK & -0.326 & -0.421 & -0.193 & -0.438 & -0.193 & -0.633 \\
\hline GG & -0.232 & -0.245 & -0.143 & -0.258 & -0.143 & -0.222 \\
\hline INV & 0.742 & 0.843 & 0.642 & 0.875 & -0.646 & 0.687 \\
\hline $1963-1986$ & BANK & LLY & PRIVATE & PRIVY & PUBLIC & PUBLY \\
\hline GG & -0.143 & -0.387 & -0.122 & -0.385 & 0.123 & -0.361 \\
\hline GK & -0.322 & -0.477 & -0.023 & -0.541 & 0.022 & -0.720 \\
\hline GG & 0.303 & 0.175 & 0.439 & 0.123 & -0.439 & -0.141 \\
\hline INV & 0.532 & 0.908 & 0.353 & 0.924 & -0.354 & 0.856 \\
\hline $1987-2003$ & BANK & LLY & PRIVATE & PRIVY & PUBLIC & PUBLY \\
\hline GG & 0.300 & 0.077 & 0.318 & 0.108 & -0.326 & -0.264 \\
\hline GK & 0.463 & 0.439 & 0.720 & 0.554 & -0.738 & -0.365 \\
\hline GG & -0.822 & -0.881 & -0.559 & -0.870 & 0.547 & 0.003 \\
\hline INV & -0.457 & -0.535 & 0.324 & -0.455 & -0.336 & -0.631 \\
\hline \multicolumn{7}{|c|}{ Lagged correlations } \\
\hline $1963-2003$ & BANK & LLY & PRIVATE & PRIVY & PUBLIC & PUBLY \\
\hline GG & $-0.135(+18)$ & $-0.060(+0)$ & $-0.337(+16)$ & $-0.109(+0)$ & $0.338(-16)$ & $-0.244(-18)$ \\
\hline GK & $-0.326(+0)$ & $-0.421(+0)$ & $-0.193(+0)$ & $-0.438(+0)$ & $-0.193(+0)$ & $-0.633(+0)$ \\
\hline GG & $-0.212(+0)$ & $-0.245(+0)$ & $0.143(+0)$ & $-0.258(+0)$ & $-0.143(+0)$ & $-0.222(+0)$ \\
\hline INV & $0.742(+0)$ & $0.843(+0)$ & $0.642(+0)$ & $0.875(+0)$ & $-0.646(+0)$ & $0.687(+0)$ \\
\hline $1963-1986$ & BANK & LLY & PRIVATE & PRIVY & PUBLIC & PUBLY \\
\hline GG & $-0.431(+16)$ & $-0.387(+0)$ & $-0.422(+16)$ & $-0.385(+0)$ & $0.423(-16)$ & $-0.487(-3)$ \\
\hline GK & $-0.322(+0)$ & $-0.477(+0)$ & $-0.023(+0)$ & $-0.541(+0)$ & $0.022(+0)$ & $-0.720(+0)$ \\
\hline GG & $0.303(+0)$ & $0.175(+0)$ & $0.439(+0)$ & $0.123(+0)$ & $-0.439(+0)$ & $-0.141(+0)$ \\
\hline INV & $0.532(+0)$ & $0.908(+0)$ & $0.353(+0)$ & $0.924(+0)$ & $-0.354(+0)$ & $0.856(+0)$ \\
\hline $1987-2003$ & BANK & LLY & PRIVATE & PRIVY & PUBLIC & PUBLY \\
\hline GG & $0.300(+0)$ & $0.374(+14)$ & $0.318(+0)$ & $0.316(+13)$ & $-0.326(+0)$ & $-0.322(-5)$ \\
\hline GK & $0.627(+18)$ & $0.439(+0)$ & $0.720(+0)$ & $0.554(+0)$ & $-0.738(+0)$ & $-0.365(+0)$ \\
\hline GG & $-0.822(+0)$ & $-0.881(+0)$ & $-0.672(+3)$ & $-0.870(+0)$ & $0.687(-13)$ & $0.518(-17)$ \\
\hline INV & $-0.659(+13)$ & $-0.535(+0)$ & $0.787(+18)$ & $-0.455(+0)$ & $-0.778(+18)$ & $-0.631(+0)$ \\
\hline
\end{tabular}


Table 6. Causality tests in B-VAR (Fischer Statistics)

\begin{tabular}{|c|c|c|c|c|c|c|c|c|}
\hline \multicolumn{3}{|c|}{$1963-2003$} & \multicolumn{3}{|c|}{ 1963-1986 } & \multicolumn{3}{|c|}{$1987-2003$} \\
\hline Variables & $F=>G$ & $\mathrm{G}=>\mathrm{F}$ & Variables & $F=>G$ & $\mathrm{G}=>\mathrm{F}$ & Variables & $F=>G$ & $\mathrm{G}=>\mathrm{F}$ \\
\hline GY DBANK & 0.099 & 0.100 & GY DPRIVATE & 1.503 & 1.611 & GY DPRIVATE & 0.124 & 0.649 \\
\hline GY DLLY & 0.375 & 1.388 & GY DPUBLIC & 1.579 & 1.541 & GY DPRIVY & 0.861 & 0.432 \\
\hline GY DPRIVY & 0.472 & 0.300 & GK DPRIVATE & 0.244 & 1.330 & GY DPUBLIC & 0.160 & 0.404 \\
\hline GY DPUBLY & 0.350 & 0.289 & GK DPUBLIC & 0.222 & 1.262 & GY DPUBLY & 0.281 & 0.560 \\
\hline GK DBANK & 0.197 & 0.277 & GG DPRIVATE & 1.452 & 0.686 & GK DPRIVATE & 1.148 & 0.594 \\
\hline GK DLLY & 0.217 & 0.636 & GG DPUBLIC & 1.490 & 0.649 & GK DPRIVY & 1.405 & 1.178 \\
\hline GK DPRIVY & 0.202 & 0.891 & DINV DPRIVATE & 1.329 & 0.119 & GK DPUBLIC & 0.692 & 0.265 \\
\hline GK DPUBLY & 0.382 & 0.616 & DINV DPUBLIC & 1.488 & 0.111 & GK DPUBLY & 0.317 & 0.285 \\
\hline GG DBANK & 0.098 & 0.224 & & & & GG DPRIVATE & 0.605 & $1.968 * *$ \\
\hline GG DLLY & 0.126 & 0.096 & & & & GG DPRIVY & 0.807 & $2.381 * *$ \\
\hline GG DPRIVY & 0.178 & 0.259 & & & & GG DPUBLIC & 0.840 & 0.977 \\
\hline GG DPUBLY & 0.129 & 0.160 & & & & GG DPUBLY & 0.763 & 0.621 \\
\hline DINV DBANK & $2.819 * *$ & 0.558 & & & & DINV DPRIVATE & 1.834 & $4.882 * *$ \\
\hline DINV DLLY & 1.647 & $2.232 *$ & & & & DINV DPRIVY & $2.584 * *$ & $2.324 * *$ \\
\hline DINV DPRIVY & $2.463 * *$ & $2.130 *$ & & & & DINV DPUBLIC & $3.126^{* *}$ & $4.136^{* *}$ \\
\hline DINV DPUBLY & $2.833 * *$ & $3.345^{* *}$ & & & & DINV DPUBLY & $2.887 * *$ & $3.542 * *$ \\
\hline
\end{tabular}

$*, * *$ indicate respectively a significant level at $10 \%$ and $5 \%$

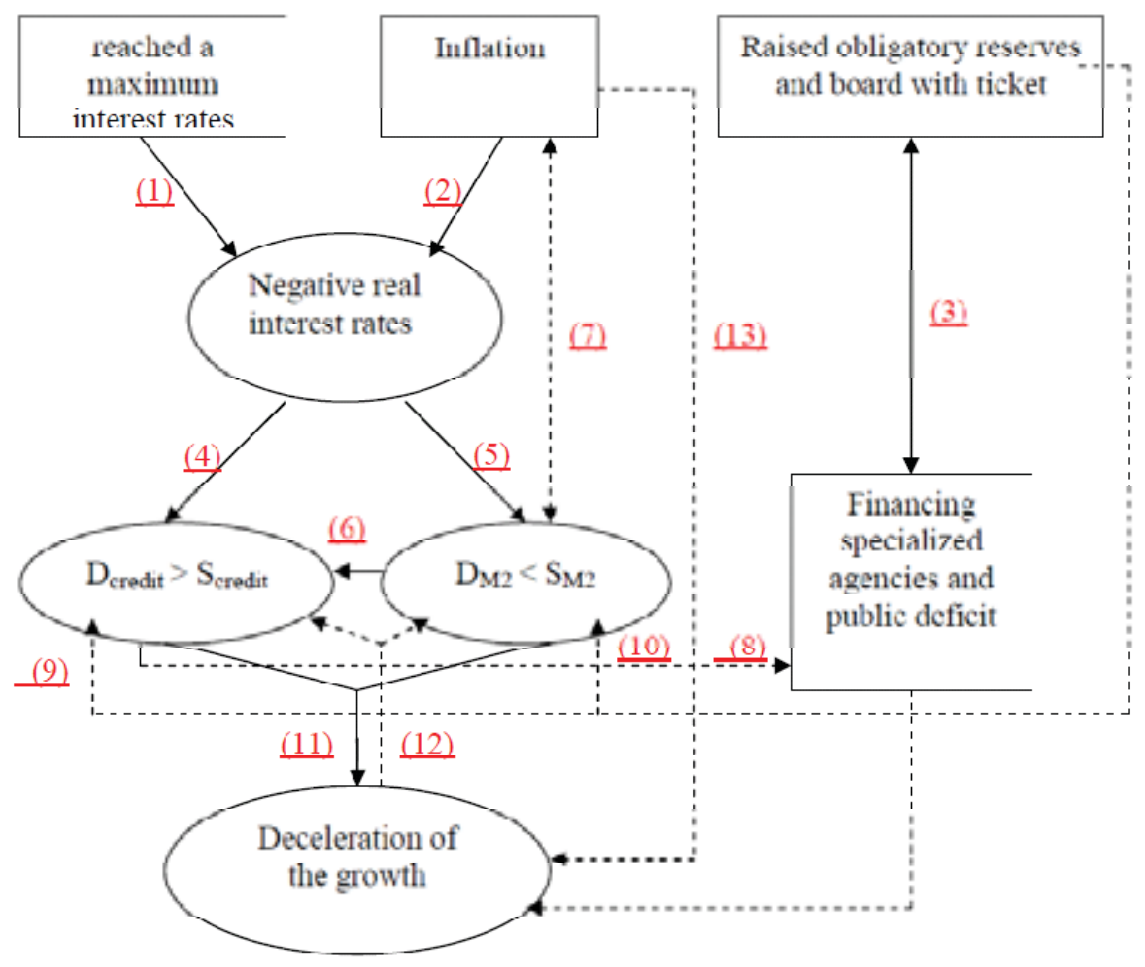

Figure 1. The impact of the financial repression 